\title{
Application of a Radioimmunoassay for Angiotensin I to the Measurement of Plasma Renin in Rabbits, and Comparison with a Biological Assay of Plasma Renin Activity
}

\author{
Hiroshi Kurihara, Akira Seki,* Toshiyuki Tanaka, \\ Jưn FuJiI* and Masao Ikeda \\ The Third Department of Internal Medicine, Faculty of \\ Medicine, University of Tokyo, Tokyo, and Institute for \\ Adult Diseases, ${ }^{*}$ Asahi Life Foundation, Tokyo
}

\begin{abstract}
Kurmara, H., Seki, A., Tanaka, T., Fujir, J. and Ikeda, M. Application of a Radioimmunoassay for Angiotensin I to the Measurement of Plasma Renin in Rabbits, and Comparison with a Biological Assay of Plasma Renin Activity. Tohoku J. exp. Med., 1975, 116 (3), 219-227—A radioimmunoassay method for ileu-5-angiotensin $I$ was applied to the measurement of plasma renin in rabbits. In the present method, the volume of plasma sample, required for the determination of plasma renin activity and plasma renin concentration, could be reduced to $0.6 \mathrm{ml}$ and $0.05 \mathrm{ml}$, respectively. A satisfactory correlation $(r=0.918)$ was found between the plasma renin activity measured by our bioassay method reported previously and that by the present radioimmunoassay method in each of 25 different plasma samples. A highly significant correlation $(r=0.968)$ was also observed between the plasma renin activity and the plasma renin concentration, both of which were measured by radioimmunoassays, as far as renin concentration remained under $200 \mathrm{ng} / \mathrm{ml} / \mathrm{hr}$. On the other hand, the present results appear to indicate that, when a high plasma renin activity was obtained, it was difficult to evaluate the actual plasma renin concentration. Therefore, it would be necessary to be cautious to apply the method for plasma renin activity on the renin rich plasma. _— bioassay; radioimmunoassay; angiotensin I; plasma renin; rabbits
\end{abstract}

Since Haber et al. (1969) and others (Boyd et al. 1969; Hollemans et al. 1969) applied a radioimmunoassay method for angiotensin $\mathrm{I}$ to the measurement of plasma renin activity in human subjects, radioimmunoassay procedures have been widely used. In the studies of experimental renal hypertension of rabbits in our laboratory, plasma renin activity had been determined by the bioassay method of Pickens et al. (1965) with a minor modification (Fujii et al. 1969). Recently we applied radioimmunoassay for angiotensin I to the measurements of plasma renin activity and plasma renin concentration of rabbits. The purpose of this paper is to describe our procedure, and to compare a biological and an immunological assay for plasma renin activity in rabbits. In addition, the correlation between

Received for publication, March 18, 1975. 
plasma renin activity and plasma renin concentration, both of which were measured by radioimmunoassays, was examined.

\section{Materials and Methods}

\section{Determination of plasma renin activity in rabbits by radioimmunoassay}

The procedure was based on the method of Haber et al. (1969) for human plasma, with minor modifications. Plasma samples were obtained from normal, hypertensive, and nephrectomized rabbits. Hypertensive rabbits were produced by constriction of one renal artery with or without contralateral nephrectomy. Peripheral venous blood was taken from the ear vein into a syringe containing heparin in the amount of about 5 units per $\mathrm{ml}$ of blood. The blood was transferred immediately into centrifuge tubes kept in ice. After centrifugation at $3000 \mathrm{rpm}$ for $15 \mathrm{~min}$ at $4^{\circ} \mathrm{C}$, plasma was taken and kept frozen under $-20^{\circ} \mathrm{C}$ until assayed. On determination of plasma renin activity, the frozen plasma samples were thawed carefully in cold. One $\mathrm{ml}$ of each sample was taken into each tube and the $\mathrm{pH}$ was adjusted to 6.5 by adding $0.1 \mathrm{ml}$ of $0.5 \mathrm{M}$ phosphate buffer, $\mathrm{pH} 6.0$. To this solution, $0.01 \mathrm{ml}$ of $10 \%$ EDTA- $\mathrm{Na}_{2}$ solution, $0.01 \mathrm{ml}$ of 8 -hydroxyquinoline $0.34 \mathrm{M}$ solution, and $0.002 \mathrm{ml}$ of $10 \%$ dimercaprol in benzyl benzoate solution were added. The volume of plasma sample could be reduced to $0.6 \mathrm{ml}$, adding all the reagents in amounts of the same ratio as before. A $0.5 \mathrm{ml}$ portion of the above plasma solution was taken into a tube, and incubated at $37^{\circ} \mathrm{C}$ under stirring for $1 \mathrm{hr}$, and the rest of the plasma solution was kept at $4^{\circ} \mathrm{C}$. The incubation at $37^{\circ} \mathrm{C}$ was stopped by putting the tube in ice cold. A generated angiotensin $I$ was determined by radioimmunoassay as follows. Standard ileu-5-angiotensin I, $\mathrm{I}^{125}$-angiotensin $\mathrm{I}$ and angiotensin-I antiserum solution were obtained from Schwarz/Mann as a kit. Reagents of $0.1 \mathrm{M}$ Tris acetate buffer $\mathrm{pH} 7.4$ solution containing $1 \mathrm{mg} / \mathrm{ml}$ lysozyme, and dextran coated charcoal (Norit A) solution diluted in barbital buffer were prepared as described by Haber et al. (1969). Into each tube, containing $0.9 \mathrm{ml}$ of Tris acetate buffer with lysozyme, $0.01 \mathrm{ml}$ of plasma samples, incubated at $37^{\circ} \mathrm{C}$ or $4^{\circ} \mathrm{C}, 0.05 \mathrm{ml}$ of $\mathrm{I}^{125}$-angiotensin I solution (about $5000 \mathrm{cpm}$ ), and 0.05 $\mathrm{ml}$ of angiotensin-I antiserum solution were added. Into each tube containing above mixture except the plasma sample to be assayed, $0.05 \mathrm{ml}$ of standards, containing $0.05-0.08$ $\mathrm{ng}$ of ileu-5-angiotensin $\mathrm{I}$ and $0.01 \mathrm{ml}$ of nephrectomized rabbit plasma, kept at $4^{\circ} \mathrm{C}$, were added. During the whole procedure, the tubes were kept cold in ice. Each tube was shaken to mix the content, and incubated at $4^{\circ} \mathrm{C}$ for $18-20 \mathrm{hr}$. Free and antibody bound angiotensin I were separated by adding $1 \mathrm{ml}$ of dextran coated charcoal solution to each tube. After mixing the content, tubes were centrifuged at $3000 \mathrm{rpm}$ for $10 \mathrm{~min}$ at $4^{\circ} \mathrm{C}$. The supernatant was disearded by decanting and the precipitated charcoal was counted for $3 \mathrm{~min}$ as the free phase. The total counts of $\mathrm{I}^{125}$-angiotensin I solution were calculated from the mean of the counts in 5 different tubes. The percentage of the free counts to the total ones was calculated at each tube. The amount of angiotensin $I$ in the plasma samples, incubated at $37^{\circ} \mathrm{C}$ and at $4^{\circ} \mathrm{C}$, was obtained from the standard curve. Plasma renin activity was expressed as ng of angiotensin I released per ml of plasma per $\mathrm{hr}$ of incubation at $37^{\circ} \mathrm{C}$.

\section{Determination of plasma renin activity in rabbits by bioassay}

Plasma renin activity was measured by the method of Pickens et al. (1965) with a minor modification as described previously (Fujii et al. 1969). About 10-12 $\mathrm{ml}$ of blood were needed for this method. The plasma was dialysed against a solution of EDTA-Na, and then incubated with added DFP, at $\mathrm{pH} 5.5$ and $37^{\circ} \mathrm{C}$ for $4 \mathrm{hr}$. The generated angiotensin was assayed on rat blood pressure by a bracket technique comparing with the standard synthetic angiotensin II aspartic $\beta$-amide (Hypertensin, Ciba). The results were expressed as the a mount of $\mathrm{ng}$ of angiotensin II equivalents formed per $\mathrm{ml}$ of plasma per $\mathrm{hr}$ of incubation. An average difference of duplicated measurements was $7.9 \%$ in 9 samples, and a coefficient of variation was $18.3 \%$ for pooled plasma, as reported previously (Fujii 
et al. 1972).

Determination of plasma renin concentration in rabbits by radioimmunoassay

The procedure was based on the micromethod to measure renin in plasma of rats, which was developed by Boucher et al. (1967) and was later applied to rabbits (Kurihara et al. 1973), except for the condition of incubation and the determination of angiotensin $I$ by a radioimmunoassay. The rabbit renin substrate, free of renin and angiotensinase, was prepared from the plasma of rabbits nephrectomized $48 \mathrm{hr}$ previously using the same procedure as for rat renin substrate described by Boucher et al. (1967). The concentration of renin substrate solution to be used, in order to obtain zero-order reaction, was determined in each new batch of the renin sukstrate. As shown in Fig. 1, in most of the batches, 50 $\mathrm{mg} / \mathrm{ml}$ of renin substrate solution was found sufficient for this purpose. To prepare the renin substrate solution in 10 determinations of plasma renin, for example, $250 \mathrm{mg}$ of renin substrate, $5 \mathrm{ml}$ of $0.25 \mathrm{M}$ phosphate buffer solution, $\mathrm{pH} 6.5,0.1 \mathrm{ml}$ of $10 \%$ EDTA. $\mathrm{Na}_{2}, 0.1 \mathrm{ml}$ of $1 \% \mathrm{NaN}_{3}, 0.1 \mathrm{ml}$ of $0.35 \mathrm{M} 8$-hydroxyquinoline, $0.02 \mathrm{ml}$ of $10 \%$ dimercaprol in benzyl benzoate solution were mixed at $4^{\circ} \mathrm{C}$, and readjusted the $\mathrm{pH}$ to 6.5 with $2 \mathrm{~N} \mathrm{NaOH}$. A $0.05 \mathrm{ml}$ portion of plasma sample was added to $0.5 \mathrm{ml}$ of the above renin substrate solution, and incubated at $37^{\circ} \mathrm{C}$ for $30 \mathrm{~min}$ or $1 \mathrm{hr}$. The reaction was stopped by chilling the tube in ice. Using 0.01 or $0.05 \mathrm{ml}$ of the incubated mixture, the amount of angiotensin I formed was determined by the radioimmunoassay as described before. As seen in Fig. 2, the separation of free angiotensin I by charcoal was effected slightly by adding the renin substrate. But, there was no significant difference on this effect among the substrates, incubated without plasma renin at $4^{\circ} \mathrm{C}$ or at $37^{\circ} \mathrm{C}$ for $1 \mathrm{hr}$. Therefore, $0.05 \mathrm{ml}$ of renin substrate solution, incubated at $37^{\circ} \mathrm{C}$ for $1 \mathrm{hr}$, was added into each tube for standard
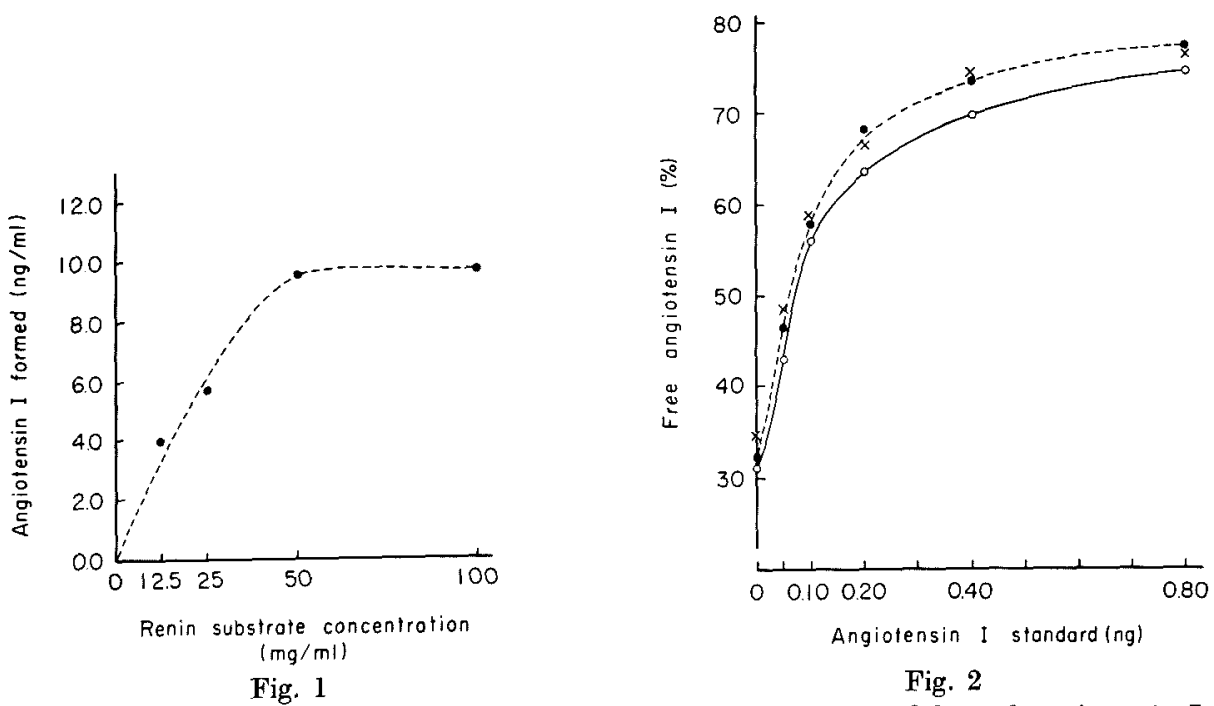

Fig. 1. Effects of renin substrate concentration on the amount of formed angiotensin I, measured by radioimmunoassay. In each determination, $0.5 \mathrm{ml}$ of renin substrate solution of different concentration was incubated with $0.05 \mathrm{ml}$ of renin rich plasma for $\mathrm{l} \mathrm{hr}$ at $37^{\circ} \mathrm{C}$.

Fig. 2. The effects of renin substrate solution, incubated without plasma renin at $4^{\circ} \mathrm{C}$ or $37^{\circ} \mathrm{C}$, on the separation of free and antibody bound angiotensin I by charcoal in the radioimmunoassay incubation mixture containing standard angiotensin $I$. Open circles, wthout renin substrate; closed circles, with $0.05 \mathrm{ml}$ of renin substrate solution kept at $4^{\circ} \mathrm{C}$; crosses, with $0.05 \mathrm{ml}$ of renin substrate solution incubated at $37^{\circ} \mathrm{C}$ for $1 \mathrm{hr}$. 


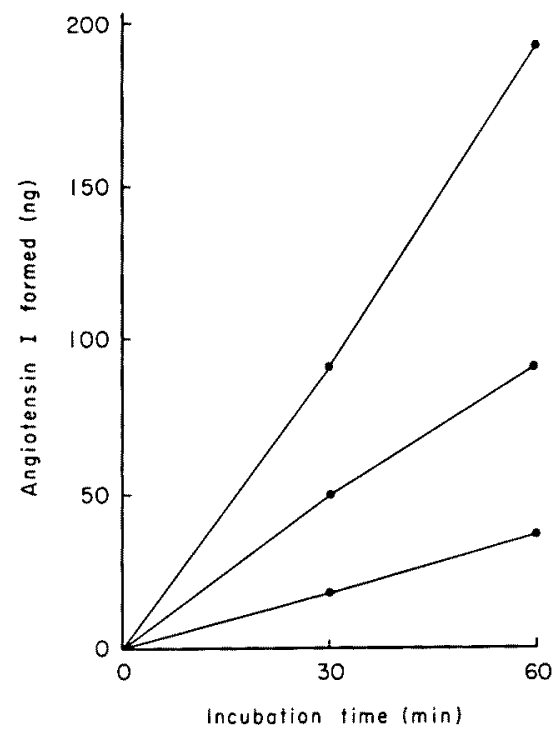

Fig. 3. Time course of the formation of angiotensin I during the incubation at $37^{\circ} \mathrm{C}$ of $0.05 \mathrm{ml}$ of each of 3 different plasma samples with $0.5 \mathrm{ml}$ of renin substrate solution.

angiotensin I. The results were expressed as the amount of ng of angiotensin I formed per $\mathrm{ml}$ of plasma per $\mathrm{hr}$ of incubation. Fig. 3 shows the linear increase of the formation of angiotensin $\mathrm{I}$ in 3 different plasma samples, incubated at $37^{\circ} \mathrm{C}$ with renin substrate for 30 and $60 \mathrm{~min}$.

\section{Results}

\section{Optimum $p H$ of renin in plasma of rabbits}

Fig. 4 shows that generation of angiotensin I was maximum when $\mathrm{pH}$ of plasma was adjusted to 6.5 and incubated at $37^{\circ} \mathrm{C}$ in the measurements of plasma

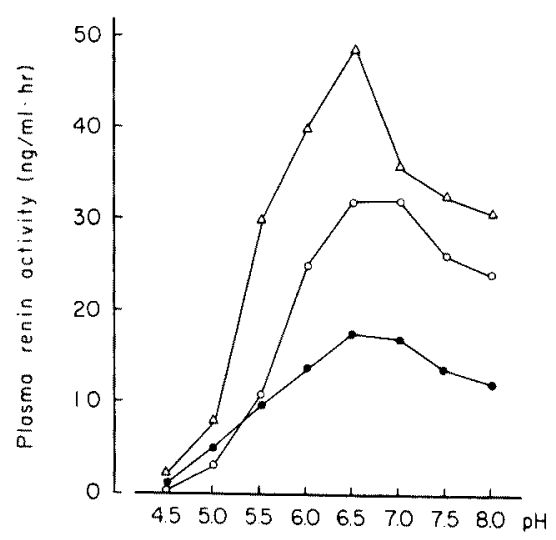

Fig. 4. Optimum $\mathrm{pH}$ in the determination of plasma renin activity in plasma samples taken from 3 normal rabbits. 
TABLE 1. Reproducibility and accuracy of the determination of plasma renin activity in rabbits by radioimmunoassay

\begin{tabular}{lccccc}
\hline & $\begin{array}{c}\text { Sample } \\
\text { No. }\end{array}$ & $\begin{array}{c}\text { Number of } \\
\text { determina- } \\
\text { tions }\end{array}$ & $\begin{array}{c}\text { Mean } \\
(\mathrm{ng} / \mathrm{ml} \cdot \mathrm{hr})\end{array}$ & $\begin{array}{c}\text { Standard } \\
\text { deviation } \\
(\mathrm{ng} / \mathrm{ml} \cdot \mathrm{hr})\end{array}$ & $\begin{array}{c}\text { Coefficient } \\
\text { of variation } \\
(\%)\end{array}$ \\
\hline Within-Assays & 1 & 5 & 2.4 & 0.19 & 7.9 \\
Between-Assays & 2 & 5 & 13.2 & 1.87 & 14.1 \\
\hline
\end{tabular}

renin activity by radioimmunoassay. It was also confirmed that maximum release of angiotensin $\mathrm{I}$ was found when the $\mathrm{pH}$ of renin substrate solution was 6.5 in the incubation with plasma renin of rabbits at $37^{\circ} \mathrm{C}$.

Reproducibility and Accuracy of the determination of plasma renin activity in rabbits by radioimmunoassay

As seen in Table 1, the values of a coefficient of variation in the within-assays in 5 simultaneous determinations of plasma renin activity in 2 different plasmas were $7.9 \%$ and $14.1 \%$. On the other hand, the coefficient of variation in the between-assays, determined on the control plasma repeatedly within the period of 3 months was $21.2 \%$. Mean plasma renin activity in 20 normal rabbits was 7.0 $\mathrm{ng} / \mathrm{ml} / \mathrm{hr}$ (S.D. \pm 5.4 ). Plasma renin activity was not detected in plasma obtained from the rabbits nephrectomized $48 \mathrm{hr}$ previously.

Comparison of the values of plasma renin activity, determined by bioassay and by radioimmunoassay

In each of 25 different plasma samples of rabbits, the plasma renin activity was determined by the bioassay method and by the immunological method independently, and plotted in Fig. 5. The correlation coefficient $(r=0.918)$ between the values obtained by both methods was highly significant $(p<0.01)$.

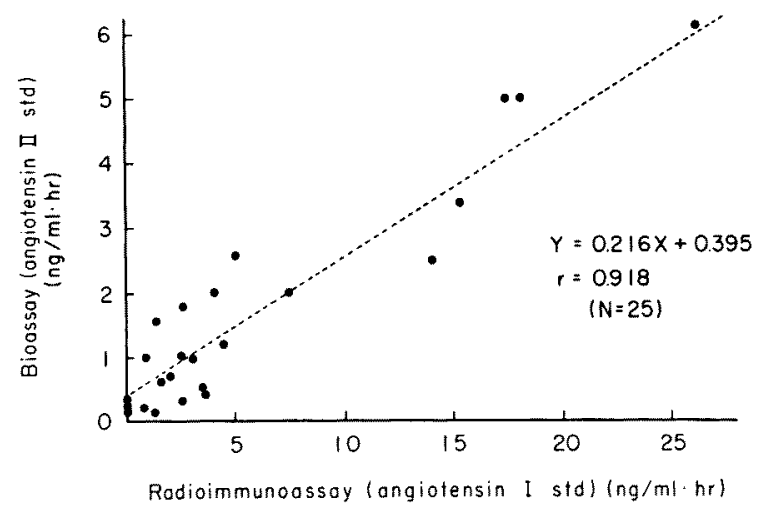

Fig. 5. Comparison of plasma renin activity determined by a bioassay and by a radioimmunoassay in rabbits. 
H. Kurihara et al.

TABLE 2. Reproducibility and accuracy of the determination of plasma renin concentration in rabbits by radioimmunoassay

\begin{tabular}{lccrrr}
\hline & $\begin{array}{c}\text { Sample } \\
\text { No. }\end{array}$ & $\begin{array}{c}\text { Number of } \\
\text { determina- } \\
\text { tions }\end{array}$ & $\begin{array}{c}\text { Mean } \\
(\mathrm{ng} / \mathrm{ml} \cdot \mathrm{hr})\end{array}$ & $\begin{array}{c}\text { Standard } \\
\text { deviation } \\
(\mathrm{ng} / \mathrm{ml} \cdot \mathrm{hr})\end{array}$ & $\begin{array}{c}\text { Coefficient } \\
\text { of variation } \\
(\%)\end{array}$ \\
\hline \multirow{3}{*}{ Within-Assays } & 1 & 8 & 16.9 & 1.34 & 7.9 \\
& 2 & 8 & 29.6 & 3.18 & 10.7 \\
Between-Assays & 3 & 8 & 43.6 & 4.51 & 10.4 \\
\hline
\end{tabular}

Reproducibility and accuracy of the determination of plasma renin concentration in rabbits by radioimmunoassay

As seen in Table 2, the values of a coefficient of variation of the within-assays were from 7.9 to $20.9 \%$ in 8 simultaneous determinations of the plasma renin concentration in each of 4 different plasma samples. As for the between-assays, a coefficient of variation of $17.1 \%$ was obtained in 6 repeated determinations of plasma renin concentration on the control plasma within the period of 3 months with a mean of $28.3 \mathrm{ng} / \mathrm{ml} / \mathrm{hr}$. Mean plasma renin concentration determined in 44 normal rabbits was $16.9 \mathrm{ng} / \mathrm{ml} / \mathrm{hr}$ (s.D. \pm 14.9 .).

Relation between plasma renin activity and plasma renin concentration in rabbits determined by radioimmunoassay

In each of 56 different plasma samples, both of plasma renin activity and plasma renin concentration were determined by the radioimmunoassay methods described in this paper, and the values were plotted in Fig. 6 on bilogarithmic scale. The plasma renin activity was well correlated with the plasma renin

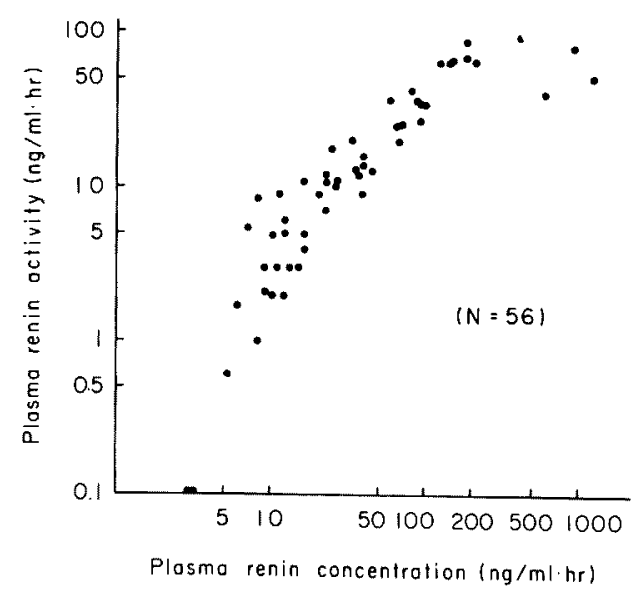

Fig. 6. Relation between plasma renin activity and plasma renin concentration, both of which were determined by radioimmunoassays. 
concentration in 50 samples, when the plasma renin concentration was under 200 $\mathrm{ng} / \mathrm{ml} / \mathrm{hr}$. A correlation coefficient $(r=0.968)$ between the results obtained by both the methods was highly significant $(p<0.001)$, and the absolute values of the plasma renin activity were expressed as about less than half ones of the plasma renin concentration. In renin rich plasma, such as over $200 \mathrm{ng} / \mathrm{ml} / \mathrm{hr}$ in renin concentration, however, the plasma renin activity was not correlated to the plasma renin concentration.

\section{Discussion}

Our previous bioassay method for the determination of plasma renin in rabbits (Fujii et al. 1969), which was based on the method of Pickens et al. (1965), needed relatively large amount of blood sample. The micromethod, developed by Boucher et al., could reduce the volume of plasma to $0.1 \mathrm{ml}$ in rats (Boucher et al. 1967), and $0.5 \mathrm{ml}$ in rabbits (Kurihara et al. 1973), but these methods still required the time consuming bioassay on rat blood pressure. In the present method, which applied radioimmunoassay of angiotensin I on renin determination, the plasma renin activity could be measured in $0.6 \mathrm{ml}$ and the renin concentration in $0.05 \mathrm{ml}$ of rabbit plasma. The volume of plasma, required in our method for rabbits, was almost the same as that in the method described by Menard and Catt (1972) for rats. The present radioimmunoassay method, which can measure renin in such a small amount of the plasma sample, has the major advantage in the experiments that required to determine the plasma renin in series during short periods of time on small animals. Furthermore, this method could perform rapidly the assay of renin on a number of samples at the same time.

The structure of angiotensin I of the rabbits has not yet clarified, but the present study showed that the radioimmunoassay of ileu-5-angiotensin I, based on Haber's method for human subjects, could be utilized in the determination of angiotensin $I$ of the rabbits.

In the present studies, optimum $\mathrm{pH}$ of renin in rabbit plasma was found at $\mathrm{pH}$ 6.5, instead of $\mathrm{pH} 5.5$, which was used in our previous bioassay method. The difference might be mainly due to the improved sensitivity of the radioimmunoassay method to detect angiotensin $I$ in the incubation mixture, and partly due to the agents added into the plasma for incubation.

It would be inevitable that the expressed absolute values of plasma renin activity, measured by the previous bioassay method, did not accord with those by the present radioimmunoassay method even determined on the same sample, because the incubation condition and the standard angiotensin I and II were different in these two methods. Nevertheless, a satisfactory correlation was found between the results obtained by the bioassay method and those by the radioimmunoassay method in the present studies. Similar good correlations between bioassay and radioimmunoassay methods for the plasma renin determination were reported by others in human subjects (Cohen et al. 1971; Sealey et al. 1972; Kotchen et al. 1973). There were practically no differences in the reproducibility 
and the accuracy in both methods. In addition, the advantages of the radioimmunoassay in the amount of plasma sample and the time required for the whole procedure, as described before, are apparent. These respects could fairly afford to replace the previous bioassay method to the present radioimmunoassay method in the measurement of plasma renin activity in rabbits in our laboratory.

In the determination of plasma renin activity, the amount of endogenous renin substrate in plasma was known to be insufficient for a zero-order reaction of renin and renin substrate in rabbits (Ryan and McKenzie 1968), and in rats (Menard and Catt 1972). In the present method, plasma renin activity was expressed as less than half values of those of plasma renin concentration. However, as far as renin concentration was remained under about $200 \mathrm{ng} / \mathrm{ml} / \mathrm{hr}$, a good correlation between the plasma renin activity and the plasma renin concentration was observed. This result appeared to indicate that the effects of consumption of renin substrate during the incubation on the yield of angiotensin I would be minimized, because the incubation time could be reduced for one hr or less, by an application of a sensitive radioimmunoassay method to determine angiotensin I yielded.

On the other hand, from the present results, when plasma renin activity was expressed as high values, it would be difficult to evaulate the actual plasma renin concentration. In determination of the plasma renin concentration, described in this paper, the amount of the volume of plasma could be reduced to $0.05 \mathrm{ml}$, and the determination of angiotensin $I$ in such a small amount of plasma, incubated with renin substrate at $4^{\circ} \mathrm{C}$, could be eliminated. From these aspects, it is preferable to determine the plasma renin concentration and this method is employed in the experiments of the rabbits in our laboratory at the present time.

\section{Acknowledgments}

We wish to express our than ks to Prof. K. Kosaka for his valuable advice and revision of this manuscript.

\section{References}

1) Boucher, R., Ménard, J. \& Genest, J. (1967) A micromethod for measurement of renin in the plasma and kidney of rats. Canad. J. Physiol. Pharmacol., 45, 881-890.

2) Boyd, G.W., Adamson, A.R., Fitz, A.E. \& Peart, W.S. (1969) Radioimmunoassay determination of plasma-renin activity. Lancet, 1, 213-218.

3) Cohen, E.L., Grim, C.E., Conn, J.W., Blough, W.M., Jr., Guyer, R.B., Kem, D.C. \& Lucas, C.P. (1971) Accurate and rapid measurement of plasma renin activity by radioimmunoassay. Results in normal and hypertensive people. J. Lab. clin. Med., 77, 1025-1038.

4) Fujii, J., Kurihara, H., Yamaguchi, H. \& Ikeda, M. (1969) Salt-rich diet and experimental renovascular hypertension in the rabbit. Tohoku J. exp. Med., 97, 191-196.

5) Fujii, J., Yazaki, Y., Kuramochi, M. \& Seki, A. (1972) High plasma renin activity and hypokalemia in rabbits with chronic renovascular hypertension. Jap. Heart J.,
$13,340-346$.

6) Haber, E., Koerner, T., Page, L.B., Kliman, B. \& Purnode, A. (1969) Application of a radioimmunoassay for angiotensin $I$ to the physiologic measurements of plasma renin activity in normal human subjects. $J$. clin. Endocr., 29, 1349-1355.

7) Hollemans, H.J.G., Van der Meer, J. \& Kloosterziel, W. (1969) Measurement of renin activity in plasma by a radioimmunoassay for angiotensin I. Clin. chim. Acta, 
24, 353-357.

8) Kotchen, T.A., Flamenbaum, W., Cirksena, W. \& Gamble, W. (1973) Comparison of a biological and an immunological assay for the measurement of plasma renin activity. J. clin. Endocr., 36, 804-810.

9) Kurihara, H., Gregory, A., Dewailly, P., Boucher, R. \& Genest, J. (1973) Effects of changes in sodium balance and of experimental renal hypertension on plasma angiotensin I converting enzyme activity of rabbits. Tohoku J. exp. Med., 109, 19-27.

10) Menard, J. \& Catt, K.J. (1972) Measurement of renin activity, concentration and substrate in rat plasma by radioimmunoassay of angiotensin I. Endocrinology, 90, 422-430.

11) Pickens, P.T., Bumpus, F.M., Lloyd, A.M., Smeby, R.R. \& Page, I.H. (1965) Measurement of renin activity in human plasma. Circulat. Res., 17, 438-448.

12) Ryan, J.W. \& McKenzie, J.K. (1968) Properties of renin substrate in rabbit plasma with a note on its assay. Biochem. $J ., 108,687-692$.

13) Sealey, J.E., Gerten-Banes, J. \& Laragh, J.H. (1972) The renin system: Variations in man measured by radioimmunoassay or bioassay. Kidney International, 1 , 240-253. 